
contained units and (b) an increase in information capacity with better vertical information systems or the creation of lateral relations. It was the early days of matrix organizing which Jay saw, understood, and put into the theory and practice of organizational design. His information-processing view was real to the manager who had to decide, communicate, and coordinate. For the academic, Jay's model was an organizational reality for framing the organizational design research challenge. It was fundamental then and is today. One way to judge a research contribution is its life span. Today, I ask my Ph.D. students to read this paper. They often ask: Why aren't there more papers like Jay's? The answer is simple: Jay got it right early on and it still stands. We continue to build upon his foundational insights. It is a rare contribution and a great legacy.

As a person, Jay had style: he listened more than he talked; he was not puffed up; he was self-deprecating; he had a good sense of humor; he spoke softly; he let his ideas carry the discussion; he was self-critical but also confident; he was firm without exaggeration; he enjoyed life as he found it.

\section{Richard Burton}

Professor, Duke University

I was intimidated by Jay's reputation when I first met him about 15 years ago. From his work, I knew how impactful his ideas had been in both the academic community and industry. As a person, I found the same pragmatism and lack of pretension in Jay that he displayed in his work. What his work didn't adequately reveal was what a warm, supportive, compassionate, and fun person he was. That combination: hugely influential, while being modest and collegial, made me a huge fan of Jay. I still am.

\section{Timothy Carroll}

Associate Dean, Moore School of Business, University of South Carolina

Jay Galbraith made many contributions to organizational design. He was particularly good at taking the different organizational designs found in the real world and articulating them within a general theoretical framework. Of his many excellent ideas, the one that most influenced me was that organizations have a volume of information to process in order to help them reach their goals, and structures and processes are the mechanisms for accomplishing this task. In saying this, I feel I am not sufficiently capturing the magnitude of his contribution to organizational design. He will long be remembered by many of us.

\section{Lex Donaldson}

Professor, Australian Graduate School of Management

Naturally, the primary thought about Jay Galbraith's contribution to the world of human resources is the Star Model. It is probably the most used idea across the global human resources community. Besides that, Jay Galbraith is really the father of organizational design practice as it exists today. Although he didn't write all of the books, he wrote many of them. And the other books were based on his groundbreaking work. We used Jay Galbraith as a consultant at my current employer, and in addition to his textbook knowledge he had interpersonal abilities that could bring any two opponents together in an organizational design project and get them on the same page. I saw it happen several times. He was a keen observer of organizational dynamics and could come up with the best answer to organizational issues, one that was stated clearly and worked. 
Jay Galbraith's 1976 book, Organization Design, was to my knowledge the first book to articulate the important idea that organization designs must include a focus on the transfer of information. Jay's book influenced my work from its publication onward, particularly my 1982 and 1983 Management Science articles on the same subject and my 1990 Academy of Management Review article and 2004 book, The Necessary Nature of Future Firms, both of which draw heavily on this idea. Jossey-Bass asked me to review the second edition of Jay's Designing Organizations (2002) for the purpose of making suggestions for the third edition (2014) of the book. I benefitted greatly from engaging in this task. Both editions richly explain the important connections between organization design and design implementation, and will certainly influence my work going forward.

George Huber

Emeritus Professor, University of Texas

Currently, I am the Global Business Process Owner for Performance Management at Cummins, Inc. in Columbus, Indiana. I had the pleasure of working with Dr. Galbraith in 2011 when I was the Global Organizational Development Manager responsible for increasing the capabilities of human resources and other units at Cummins. I hired Dr. Galbraith to do a customized workshop. I authored the case study material used in the course under his coaching and guidance. He told me that it was very well written and comparable to that of Harvard Business School students. I also designed the workshop and developed the material, leveraging Jay's expertise and wisdom as a sought-after thought leader in organizational design. He was a humble man of great wisdom and knowledge. I learned from him the art of building a real-life case study that could be further developed and leveraged post-training. It was an incredible experience to work with him, and he will truly be missed in my life and the lives of many, I'm sure. Thank you so much for the opportunity to work with you, Jay, and to share my thoughts. May God bless you now and forever and those loved ones you left behind.

Jácquelyn Eley Jean-Claude

Cummins, Inc.

I first met Jay at the national Academy of Management meeting in Kansas City in 1975. I had already thoroughly studied his groundbreaking first book, Designing Complex Organizations, as part of a field experiment in matrix structure I was conducting at the time. He was already a mentor to me, even though the relationship was only through his writing. He hired me at the Wharton School when I finished my Ph.D. that year, and I inherited his great course in organizational design when he left Wharton shortly thereafter.

Jay was not only my mentor; he was also a close personal friend. Because we often worked and traveled together I got to know him very well. Others contributing to this project will undoubtedly speak of Jay's many contributions to organizational design. I believe that my comments will be most interesting and complementary to those of others if I focus not so much on his achievements, which were many, but the way he thought about things, his personal qualities, and why his work is so valuable.

Once while having dinner and discussing organizational design (as we usually did), Jay provided an elaborate and convincing argument that academics were not advancing the field of organizational design. In his opinion, it was managers who were innovating new organizational forms, and he believed that academics must look to those innovations as a source for advancing the field. The search for new organizational forms dominated his career as both an academic and a consultant. When he found new forms, he added something to them that speaks to the personal qualities I mentioned above and that greatly inform the theory of organizational design.

Jay was very humble for a person with so many accomplishments. He studied with James D. Thompson and was deeply influenced by his thinking, as was I. Jay often said to me he really hadn't added much to organizational theory - all that he had done was "re-say Thompson, in 
words that people can understand." Of course, it was far more than this, but Jay's humility and interest in practice resulted in the greatest contributions to the field of organizational design of any scholar to date. Jay studied new organizational forms that emerged with their roots firmly in practice, but did it in a way that made fundamental and enduring contributions to theory. He always worked from practice to theory and not the reverse.

When I left Wharton to join the Tuck School at Dartmouth in 1983, one of my then senior colleagues remarked that this would be good for my career. I asked him why, and he said that I was a promising researcher who had been led astray by Jay Galbraith. Jay and I often laughed about this, usually in a great restaurant, while working on a project of significant practical import. Like the protagonist in Robert Frost's poem, "The Road Less Taken", I believe that I too "took the road less travelled by, and that has made all the difference."

Thank you, Jay, for showing me the way.

William F. Joyce

Professor, Dartmouth College

This may sound simplistic but Jay made me realize how much people matter in implementing an organization design. Though "people" have always been represented as one point in his Star Model, it was his later work on matrix organizations and information flows through senior personnel that really hit home the importance of aligning internal stakeholders and decision makers. His examination of how organizations can effectively use executive rotation programs to foster this alignment and better process knowledge was a significant contribution to understanding the issues of increasingly complex organizations.

Samina Karim

Associate Professor, Boston University

The question of "What ideas or insights regarding organization design have you obtained from the work of Jay Galbraith" is not easy for me to answer briefly. I knew Jay for twenty years, and no one has been more important to my professional identity, success, and knowledge base as he has been. As a young consultant, when I first heard him speak at Citibank in 1994 I didn't honestly understand what he was talking about, but I knew this was someone I wanted to learn from. When he asked my late partner, Diane Downey, and me to write a workbook with him in 2000 it was an honor. That work became the start of my deep education in organization design. Over the next ten years, Jay and I taught organization design, spoke at conferences, consulted with clients around the world, and wrote another book together. I see my professional focus as building on Jay's work and spreading his ideas, now with my partner, Greg Kesler.

Every book, article, presentation, and program that I am involved with always starts with the Star Model. That profound model is at the core of everything I do. But, another idea of Jay's also pervades almost all my work. He taught me about complexity. I frequently paraphrase him: "A complex strategy cannot be achieved with a simple organization. But, you must keep it simple for the customer and the front-line employee. Therefore, it is management that has to shoulder the complexity of multi-faceted strategies and multi-dimensional organizations. That is why we need to focus on management processes, building networks, and creating metrics and people processes that encourage collaboration where it is needed." Regardless of what a leader is specifically trying to achieve, I find that following this straightforward guidance always leads to a better design and a clearer path to successful implementation.

Amy Kates

Co-founder, Kates Kesler Organization Consulting 
Jay stands out as the single most important thinker in the field of organization design, to be sure. His influence on me started in the fall of 1975 in a graduate course where his book on strategy execution was required reading. His first book in the Addison-Wesley OD series was the next of his books added to my early library. So the impact of his work was foundational for me, and it is impossible to over-state the importance of that work for a 24-year old, aspiring OD professional.

There are two things that stand out, however, as I reflect back over the subsequent forty years of his work. The first is his true originality. There is simply no one who created as much original thinking in the field. In a way, most of the work that others did was derivative of Jay's books, which kept coming over the years, always with new thinking and constructs for the rest of us to work with.

The second standout for me is the extent of his global business knowledge. Jay was a business management expert first. His understanding of financial markets, global competitive markets, and industry segment knowledge astounds me. His work was all the more impressive due to his ability to connect his organizational models to the business world that companies are struggling with. And he kept that business knowledge current, evident in his later writings on the impact of digital technology on business and organization.

His impact on the field of organization development is well known to all. His impact on my thinking and approach to the field was simply enormous.

Greg Kesler

Co-founder, Kates Kesler Organization Consulting

I came across Jay Galbraith's work while participating in ODC's conference on Big Data and Organization Design in 2013 and deliberating the implications of big data and analytics for organization design. Galbraith may be best known for his Star Model, but for me his conclusions on the co-development of strategy and structure have been of particular value. His insights pertaining to the need for multi-dimensional matrix structures in the face of increasingly complex organizational contexts are ingenious and of perennial quality.

\section{Janne Korhonen}

Ph.D. Candidate, Aalto University

Jay Galbraith was a pioneer and leader in the field of organizational design, helping to establish the field as a proper business and academic discipline. His famous Star Model recognizes the point that business capability is critical to the success of a business, and it requires structure, process, rewards, metrics, and talent to be aligned with the strategy of the business to establish such a capability. Great work, great man.

Paul Lambert

Associate Director, Hay Group 
During my thirty-plus years of knowing Jay and using his Star Model, I can say it profoundly impacted how I (and Procter \& Gamble) thought about organization design. This powerful tool taught us about the need to: (a) look at an organization's design holistically, (b) begin with strategy (or purpose) and then address the other organizational building blocks, and (c) recognize that design is all about making choices.

Most importantly, I learned from Jay how to be a consultant, teacher, mentor, and friend. He was ALWAYS there when you needed him. He was a voracious learner, always seeking to pick up new ideas. He loved life and will always be someone I deeply admired and sought to emulate.

Keith Lawrence

Procter \& Gamble

Jay Galbraith's brilliant insights about knowledge work in engineering organizations have been seminal to my research over the past three decades. Jay's primary insight for my work was that "exceptions" - information/knowledge shortfalls that arise during task execution and thus require input from others - can be viewed as simply another kind of knowledge work that adds to the quantity of work to be done by members of an interdisciplinary project team. This insight was the inspiration for my research group to develop the Virtual Design Team simulation of cross-disciplinary project organizations engaged in fast-paced, concurrent engineering work.

Inspired by Jay, my graduate students and I quantified the magnitude of exceptions in typical engineering organizations and implemented a discrete event simulation of information processing and flow through an organization required to carry out direct work, supervision, and coordination. Following Jay - and Burton and Obel - we assumed that organizations must have the requisite information-processing capacity at every node to process the amount of information needed to carry out direct work, plus handle exceptions related to both supervision and coordination. Moreover, following Jay, we asserted that this is a necessary but not sufficient condition for successful project execution. Jay and I talked about how requisite information-processing capacity was the equivalent of "information-flow physics" for project or company organizations. Using a civil engineering analogy from my own field, if the physics is wrong, the bridge collapses immediately. If the physics is right, the longerrun success of the organization (or bridge) depends on getting the chemistry correct to avoid "corrosion" and attendant loss of load-carrying capacity.

Jay's subsequent work on the "physics and chemistry" of matrix organization structures and how to make them work effectively was also an inspiration for much of my own organization design consulting to large, multidisciplinary engineering and construction organizations.

Jay was both an insightful and constructive critic of our project organization simulation research, and an inspiring mentor and colleague in consulting engagements in which we collaborated.

I join my colleagues in the Organizational Design Community in celebrating Jay Galbraith's prolific and influential writings on organization design, his inspired teaching at multiple universities and conferences worldwide, his path-breaking organization design consulting practice, his good humor, and especially his decency and humility. Jay will be sorely missed by our community.

Raymond E. Levitt

Professor, Stanford University 
My work on organizational design has been heavily influenced by Jay Galbraith's contingency and information-processing perspective, which I believe has become even more relevant and insightful given that (a) today's environment is becoming increasingly dynamic and relational in nature, and (b) organizational researchers like myself have relied more on informationbased modeling techniques that can account for more contingency conditions.

Zhiang “John” Lin

Professor, University of Texas at Dallas

I consider Jay Galbraith to be the preeminent thinker in the field of organization design. As such, Jay's thinking informed most everything I do in my work. Whether it is his own perspective or the clear way he summarizes the field, it is impossible for me to pick out a specific idea or insight as it is the whole of his thinking that informs my practice. I will miss his reflections on how organizations optimally operate and his clear way of describing the sometimes complex issues associated with design. I will continue to draw on his writings and, hopefully, generate new insights to make up for his absence.

Eric Lloyd

OD Director, The Clorox Company

Jay's work on the information-processing view heavily influenced our studies on the use of collaboration software in large multinationals in the 1990s, especially on complex global machinery construction projects (and the impact of using Lotus notes software on coordination challenges). This resulted in a widely used Harvard case, a dissertation, and several articles. We are still following his ideas in how software development work is coordinated in open source software projects. His ideas are always inspiring due to their simplicity, clarity, and conceptual power.

Kalle Lyytinen

Professor, Case Western Reserve University

It is Jay Galbraith's explanation about organization design through his Star Model that shows an organization is more than just a structure; an organization includes processes, people, and rewards as well. Galbraith communicates this message about organization design with equal success to three different worlds: academe, practice, and students.

Academe speaks the language of scientific theory using words in a way to describe a coherent and internally consistent system in which conclusions follow given laws and premises. The world of practice seeks empirical content - words that refer to things that can be observed, or at least have implications that can be observed. Sometimes when we are using "common" organization design terminology when speaking with practitioners, we may experience them looking puzzled. Though organization design is a practice-oriented field of social science, practitioners often do not understand the language we use. The misunderstandings might come from the fact that some organization design terms are also used in everyday conversations but do not necessarily cover the underlying complexity of the phenomenon. Galbraith's approach to organization design communicates fluently with both of these, often detached, worlds. His work is built on scientific rigor but does not put aside the practical aspect of the discipline. His approach to organization design and language used is easily absorbed and applied by managers practicing organization design every day in their work.

I deliberately differentiated the world of students from the world of academe. Students are a particularly important group because they have little practical experience. Based on my teaching experience in organization design, I recognize that they accept the Star Model as one of the best explanations of organization design. 
The work of Jay Galbraith inspires me as a teacher, consultant, and an author in the field to shape my work so that it can be understood by or easily translated for each of the three worlds in organization design: academe, practice, and students.

\section{Ana Aleksić Mirić}

Assistant Professor, University of Belgrade

Jay's work was not theoretical but intimately tied to business issues, both strategic and operational. His books were highly relevant and reflective of the economic, technological, and business needs of their time, ensuring that I never lost sight of the reason(s) for a particular design approach or configuration. Because he was such an extraordinary observer, his analyses were based on well-organized and transparent empirical data and experience. He opened a window to the world's largest, global, complex businesses, to which most of us practitioners did not have access. He brought us real and workable solutions, ones that we could incorporate into our own work, regardless of size and scope.

In short, I learned from Jay that (a) there is no one "right" solution; (b) what works for the client and their strategy is the "right" design at the time; (c) no design is final; and (d) designs evolve to meet the needs of the organization and its environment. Jay showed us year after year at Organization Design Forum conferences that the fun of design never ends - in the joy he shared in learning about new challenges and new creative design responses. I assume he is still designing, wherever he is now.

Kathy Molloy

Principal, ChangeWorks International

I knew Jay through his books. I remember when the first one came out it was chock full of useful perspectives to help me think through the design issues of some of my clients. The notion of information flow/exchange/processing was my first takeaway, and it is still valuable today.

Gene Morton

Consultant

Jay Galbraith's idea of designing an organization where the information-processing demand is met by the organization's information-processing capacity has been one of the fundamental ideas on which my research on and application of organizational design has been based. As simple as this idea may sound, it has been shown to be both powerful and sustainable. This principle has allowed many areas of research to be brought together into a multi-contingency model of organizational design that has significant predictive power. Also, Jay's idea has become even more relevant in a world of dramatic increases in information availability and sharing. Information processing has to be a concern of every organization today. I had the privilege to work with Jay on getting the Organizational Design Community up and running. He never turned down a request. His work and personality will continue to be a great inspiration.

Børge Obel

Professor, Aarhus University

So, you want to create a government from scratch? And you want it to be a new kind of government in which the people, rather than the "subjects," choose their leaders and determine the course of the new nation? Such was the dilemma faced by our Founding Fathers. As Alexander Hamilton and James Madison summed it up, "In framing a government which is 
to be administered by men over men, the great difficulty lies in this: you must first enable the government to control the governed; and in the next place oblige it to control itself."

As the social, technological, and political environment changes, organizational structures must adapt. The challenge has been to ensure the organizational structure keeps up with the changes since its inception and adjusts to the environmental landscape while keeping intact the original governmental functions. Changes are constant in an ever-changing system like a national government. The work of Jay Galbraith has been instrumental in this endeavor for the U.S. federal government. Much of the work done in this area has been influenced by Jay's ideas even if all the practitioners did not know they were following a specific methodology or that it came from Jay Galbraith.

Recent examples include the inception and development of the Consumer Financial Protection Bureau (CFPB). CFPB was established under Title X of the Dodd-Frank Wall Street Reform and Consumer Protection Act ("Dodd-Frank Act"). To create a single point of accountability in the federal government for consumer financial protection, the Dodd-Frank Act consolidated many of the consumer financial protection authorities previously shared by seven federal agencies into the CFPB and provided the Bureau with additional authority. This agency did not exist prior to this point and was designed and built to meet the letter of the law with three separate functions: Educate, Enforce, and Study to give consumers the information they need to understand the terms of their agreements with financial companies; work to make regulations and guidance as clear and streamlined as possible so providers of consumer financial products and services can follow the rules on their own; and research consumer behavior to ensure success of the first two areas.

Another recent example is the Office of the Comptroller of the Currency (OCC), which took over supervision of 700 institutions and absorbed 700 employees from the Office of Thrift Supervision (OTS). This regulatory merger came under the Dodd-Frank Act. Lawmakers wanted to end the ability of lenders to shop regulators, which Countrywide Financial Corp. did in 2007 by switching from the OCC to the OTS. Just one year after the switch, the failing mortgage giant was forced to sell to Bank of America in a fire sale. The OCC issued final rules on how it will govern these smaller institutions. For instance, it added language, clarifying that federal savings associations will be subject to the same standards as national banks when determining if a state law obstructs or impairs a bank's powers. The OCC also revised rules on investigations, allowing state attorneys general to bring enforcement actions in court to enforce applicable state laws. After the transition was complete, the OCC provided a single assessment schedule for both national banks and federal savings associations. The agency appropriately tightened its process for preemptory decisions, and the merger will solidify regulations under a single umbrella. This makes sense in a national economy. An efficient, well-regulated national system makes it easier for banks to grant credit to customers across state lines, promotes job creation, and preserves our industry's competitive structure. A patchwork quilt of inconsistent state laws drives up the price of financial products and makes consumers' financial lives more complicated. Both of these illustrations are examples of how the work of Jay Galbraith has influenced the creation of a new entity and how it influenced the concatenation of two separate agencies into one effective organization, all guided by law and influenced by ever-changing financial and political forces.

A third example of the organizational design work done in the federal government and influenced by Jay Galbraith is the Financial Crimes Enforcement Network (FinCEN). FinCEN carries out its mission by receiving and maintaining financial transactions data; analyzing and disseminating that data for law enforcement purposes; and building global cooperation with counterpart organizations in other countries and with international bodies. FinCEN exercises regulatory functions primarily under the Currency and Financial Transactions Reporting Act of 1970, as amended by Title III of the USA Patriot Act of 2001 and other legislation, a legislative framework commonly referred to as the "Bank Secrecy Act" (BSA). The basic concept underlying FinCEN's core activities is "follow the money." The primary motive of criminals is financial gain, and they leave financial trails as they try to launder the proceeds of crimes or attempt to spend their ill-gotten profits. Law enforcement agencies successfully use similar techniques, including searching information collected by FinCEN from the financial industry, to investigate and hold accountable a broad range of criminals, including 
perpetrators of fraud, tax evaders, and narcotics traffickers. More recently, the techniques used to follow money trails also have been applied to investigating and disrupting terrorist groups, which often depend on financial and other support networks. This entailed building an organization around the collection, analysis, and dissemination of "big data" which is shared both nationally and internationally. This is not unique, but the scale and speed in which the organization needed to function was a design requirement new to the federal government. Jay's writings on how to incorporate big data analytical capability into an organization were very helpful in this regard.

These are but a few examples of the work done and influenced by Jay Galbraith's work in Washington, D.C. I have been the lead consultant on dozens of organizational design and organizational development activities in the federal government for over 12 years and have always guided and educated my clients on the methodologies formulated and influenced by Jay Galbraith. My first work and interaction with Jay Galbraith's body of work was in the early 1990s while serving in the military and working on a joint taskforce to solve the issue of inter-communication among the services during conflict engagement. My involvement came about from an incident of fratricide I was involved in, when my special operations ground team was engaged by friendly fire from an aircraft. We did an analysis of how to minimize this type of incident in the future and what processes and procedures to put in place. We used the Star Model to ensure that what we solved did not cause other organizational or procedural problems. The problem still exists today, but there is a much lower incident rate because of our work and the influence of Jay Galbraith.

The work of Jay Galbraith has always been a guiding beacon of my practice and has continuously helped me engage and define for my clients the reasons and purposes for the actions I have taken with them. Thank you, Jay!

Brent Oberholtzer

CEO and Founder, Org-Ology

This was a recent blog post we featured on the Organization Design Forum's website written by one of our Board members. On behalf of the Board of Organization Design Forum, we'd like to submit the following for your tribute article.

\section{Jay Galbraith and ODF, a Memory and Tribute}

I always look forward to the Organization Design Forum (ODF) Conference, but this year I am particularly anticipating being in my professional home. We have lost one of our own, a dear thought leader in our field, and I am eager to come together as a community to remember his contribution to our profession.

Jay Galbraith died on April 8, 2014, and we are all reeling from the news. He was as alive a person as you could ever see. He was working with clients and writing books and articles up until his death, and he reminds us that if we do what we love, it doesn't seem like work. In 2004, at my first ODF Conference in Chicago, I found myself feeling anxious, while privileged, to be in the midst of the likes of Stu Winby, Bill Pasmore, Paul Tolchinsky, and Dick Axelrod, just to name a few. My colleague, Dr. Craig McGee, and I busily prepared to make our presentation on a design project where our approach was based on the Galbraith Star Model (Designing Complex Organizations, 1973). I had been an eager student of Dr. Galbraith's work while in graduate school and found it a simple and pragmatic organizing framework that was also easily understood by the client. As I turned around to begin the presentation, Jay had walked quietly into the back of the room and sat down. I couldn't believe it. There he was! In person! Real life! My voice quaked as I welcomed the group and began to tell the story of a project that is still one of the high points of my career. We had led the leadership team through strategy development and were in the midst of the design work. When I finished and was mingling with participants, Jay took me gently by the arm and said, "Well done. And, remind your client that strategy is never done." Ever the teacher, mentor, researcher, learner. 
Jay embodied what I love about ODF. We come together to learn, to push each other, to share and to support. Our work can be lonely and difficult. It is a pleasure and a privilege to be among such accomplished and generous colleagues and a relief not to try to explain what we do. We all know what we do and the conversations start at deeper points.

I feel lucky to be part of a profession that was led by a man such as Jay Galbraith. He was brilliant, humble, and committed to making our field more accessible and respected. He showed his commitment to ODF by working on our Advisory Board, contributing to our thinking, and supporting us as we worked on ways to meet the expectations of our community members. We are in debt to his trail-blazing thought leadership, and I look forward to coming together as a community to honor him and renew ourselves in his spirit.

With the news of Jay's passing, it feels the perfect time to take stock and consider his influence on our work and to think about what's next for our field.

Claudia Murphy

ODF Board Member

We appreciate your efforts in assembling this tribute on behalf of Jay. His loss will be felt in our community worldwide.

Sincerely,

Organization Design Forum Board Members:

Emily Axelrod, Nuala Campany, Todd Christian, Rick Hardin, Wendy Helmkamp, Lisa Kimball, Diana Larsen, Evan Leonard, Claudia Murphy, Jude Udedibia, Stuart Wigham, Bill Zybach

Jay's work, in the design and deployment of his Star Model, has been a cornerstone of my professional practice for the last ten-plus years, facilitating organizational design change initiatives from the basic to the transformative, while also leaving leaders at all levels with a deeper understanding of capability through the model's applicability and simplicity.

Jay also had a way, because of his thorough understanding of both the academic and practitioner communities, of truly bridging the gap between the two, by empirically validating elements of his model while ensuring its business applicability. On behalf of Jay, we within this collective community have an opportunity to continue his legacy of "applicable application" by seeking out and embracing the value each community can bring to continue to evolve our practice and enable achievement of this larger purpose architected by Jay Galbraith.

Tracy Platt

Senior HR Director, CVG Strategic Initatives, Medtronic Inc.

Jay R. Galbraith, who transformed the field of organisation design, and was the creator of the highly influential Star Model of organization development, passed away on April 8, 2014, at the age of 75 .

I first encountered the ideas of Jay Galbraith as a doctoral student in the late 1990s, nearly a decade before I encountered him in person.

At the core of Jay's thinking was a vision of organizations as collections of individuals that must process information, individually and collectively, in order to achieve the organization's goals. Therefore, an organization's design should take into account the amount of information required to be processed by its decision makers. When uncertain business conditions demand that the organization assume a greater informational burden, the design must be altered.

I remember being amazed by three things about his first book that I read in a doctoral seminar. First, the sheer ambition and courage of his ideas. Jay meant to do nothing less than provide a complete toolkit to analyze and design complex organizations of all shapes, 
sizes, and sectors - and he wanted to do that in a slim volume of around 150 pages. Second, the anchoring of his arguments in concrete detail, gleaned unmistakably from first-hand experience. Third, the humility with which Jay presented this ambitious set of ideas. For instance, in the preface to his 1973 book, Designing Complex Organizations, he wrote: “... A third warning is that the reader will find nothing new... What I have tried to do is synthesize a number of phenomena which are usually treated separately... It is this synthesis which is the contribution, if any, that this book makes." He went on to acknowledge his intellectual debt to the founding fathers of modern organization design theory: "I have been influenced by James D. Thompson. It was he who influenced me to begin studying organizations and provided a basis for some of the content. The other person is Herbert Simon. There are times when it seems to me that I have merely rewritten his thinking on the basis of the last ten years' empirical evidence."

As I read more of Jay's work (he was always Professor Galbraith to me), I began to appreciate why his name had become synonymous with the theory and practice of organization design. His ideas were fairly abstract, but around this core, Jay built a detailed framework that interpreted structural features of organizations such as hierarchy, departmentalization, policies, lateral roles, and so on in terms of their information-processing functions. This mapping from structure to function later became an integral part of all the thinking about and research on organization design.

A final layer of ideas involved how to make these concepts useful to those who design organizations. Jay's Star Model identified five key "levers" — strategy, structure, process, people, and rewards - by which managers can shape employee behavior toward a desired outcome. It is easily one of the most influential ideas of all time in the world of practical organization design and change.

At some stage, I discovered, to my surprise, that Jay used to be a professor at the same business school where I was studying for my doctoral degree (Wharton). I wondered what had prompted a successful theorist like him to give up academia for the world of practice. I lost no time in asking him that the very first time I met him, at a small workshop in Brussels many years later. His candid answer basically was that he left academia when his ideas began "turning out to be too useful to publish." Around 1979, Jay said, he began getting more requests for consulting than the academic rules would allow. He felt he was learning a lot through these projects, perhaps more than through his regular academic position, so he resigned his professorship. That must have taken courage and intellectual ambition of an unconventional sort. As he wrote in his book Designing Matrix Organizations that Actually Work in 2008: "My academic colleagues thought I was crazy. In part they were correct. I have never regained my academic credibility." This was patently false, of course, as his evergrowing citation count within academic circles clearly showed, but he could never overcome his innate modesty.

Over the years, I got to know Jay, particularly in his role as co-founder of the Organizational Design Community. This initiative aims to put organization design squarely back onto the academic agenda, from where it has gone missing for a couple of decades and to ensure it gains the same importance there that it already enjoys in the world of practical management. Over multiple meetings, discussions, and brainstorming sessions, I repeatedly saw in Jay the same attributes that so impressed me about his early work: Ambition, courage, an anchoring in reality, awareness of the latest phenomena, and above all, a sense of humility. His very last paper was about the organization design implications of big data, and the third edition of his book, Designing Organizations, hit the shelves two months before he died and was a total rewrite of the second edition.

I last saw Jay at a conference in 2013. We were enjoying what felt like a well-earned drink at the end of a long day, and I casually mentioned a doctoral student at INSEAD who wanted to build agent-based models of matrix structures for his dissertation. Jay's eyes lit up; for the next thirty minutes I got a glimpse of the kind of academic he must have been as a younger man. He laid out the problems with the pessimistic rhetoric about matrix structures ("utter nonsense!"'), and how the label itself was being bandied about without any precision. He cited examples from his extensive experience, and we argued a bit about what would be a good way to abstract from the phenomenon in a useful way. Jay was clearly excited by the prospect 
of an analytic look at the phenomenon and couldn't wait to read the work.

That's the Jay Galbraith I will always remember.

Phanish Puranam

Professor, INSEAD (Singapore)

In tribute to Jay Galbraith from a four-decade student of his work: "In the narrative sense of organizational architecture, Jay has truly given us our solid foundation, the strength and drive behind all future Organizational Design and Development."

James Grant Regan

CEO, QaBe Developments

Jay Galbraith's major accomplishments arose from his ability to combine theory and practical application. In my own quest for creating synergy between the academic side of organization design and practical experiences in doing design projects in authentic organizational settings, I consider Jay's work as one of the very few role models available. As such, Jay's ability and perseverance in travelling back and forth through the entire knowledge chain, from client problems and challenges to tooling and academic theorizing, has been exceptional. From Jay, I therefore learned two things. First, Jay's scholarly work inspired, and continues to inspire, me in bringing together and systematically connecting the worlds of "design" and "science" in the management discipline. And, second, Jay's professional life has demonstrated that such a quest is not only a prerequisite to becoming a truly professional discipline but that it also is an entirely feasible course to pursue.

Georges Romme

Professor, Eindhoven University of Technology

I learned three things from the work of Jay Galbraith that have served me throughout my career as a strategy and organization professor.

Jay was trained as both an engineer and a management researcher, so he knew how to study organizational behavior in a rigorously analytical way. But he was equally interested in the practical side of organizations. He always sought to know how a particular organization should be designed so that it could accomplish its purpose. As a result of his insight and emphasis on practicality, everything I ever read by Jay made sense to me. His work was always current and useful, and I tried to emulate his approach to studying organizations as much as I could.

Jay wrote an influential article in 1974 entitled "Organization design: an information processing view." In that article, he laid out the fundamental idea that an organization's design should help the organization process information. Thus, a good design helps the organization gather and analyze information, make decisions and formulate plans, and learn. This is the essence of organizational behavior.

Jay wrote about what he called "enterprise" designs - organizational structures and processes used to operate the total enterprise. Jay consulted with some of the largest, most complex organizations in the world. Alfred Chandler, a business historian, had chronicled the rise of American enterprise designs from their origins in the railroads in the late 1800 s to the large multidivisional corporations of the post-World War II period. Jay began his work where Chandler left off and carried it through to the present day. Jay wrote a book about each major development in enterprise design that has occurred since the 1960s. Each of his books is rich in insight and description, and they have been an inspiration to me in how to write clearly and sparingly.

Charles Snow

Emeritus Professor, Penn State University 
I co-authored an article in Spanish last year with Jay, which focused on the organizational challenges of Colombian companies in expanding into other countries in the Americas region. I was delighted to write this article with him and impressed by his humility and generosity to contribute on this topic, especially since we met virtually through Linked-in. I am enclosing the article so that you can include it in the tribute that you are preparing to this wonderful and insightful colleague.

Alvaro Triana

Director, Triana, Uribe, and Michelsen LTDA

Jay Galbraith has been influential in shaping the discipline of organization design for more than forty years. He has created a theory of organization (around information processing), provided a logic for how to diagnose and improve organizations (his Star Model), defined the choices and consequences for alternative organization designs, and advised hundreds of companies on how to make sure that their organization is designed to deliver desired results. Jay's work has also shaped the professional lives of most organization designers today. The genealogy chart of those he has directly and indirectly influenced would include business leaders, human resource professionals, organization consultants, and academics who have built their research logic on his insights.

At a personal level, Jay helped me refine my thinking more than thirty years ago. In the 1980s, there were many "organization models" being used: McKinsey had the 7-S model; Dave Nadler and Mike Tushman had an organizational architecture framework with congruence of key systems; Russ Ackoff (and others) were advocating systems models for organizing. Entering into this fray, Jay's Star Model became a standard that both synthesized and extended this organizational diagnostic work. He was able to elegantly and simply define the key processes for an organization and then articulate choices both for those processes and for their alignment with each other.

At the same time these organizational process models were being deployed, others were looking at organizations as bundles of capabilities. For example, C.K. Prahalad and Gary Hamel worked on the "core competence" of the organization, focusing on technical competencies around which to integrate organizational practices. Dale Lake and I published Organization Capability to define the culture requirements of an organization. We proposed managing the organizational practices to define and deliver organizational capabilities. We were particularly interested in how human resource practices could build competitive advantage through better alignment of those practices.

I was privileged to do workshops with Jay where he would present his organizational diagnosis models, and I would present some of the culture and capability models. I will always remember a conversation with him in a car to an airport after one of these workshops where he graciously challenged me to extend my thinking. He asked a simple question, How can you specify the critical capabilities that an organization needs to succeed? We had been advocating organization audits, but we were not clear about articulating the capabilities that would create uniqueness and add value to customers. I pondered on his question then and in the ensuing years.

We have since become much more rigorous about what we mean by organizational capability, how capabilities can be defined and measured, how they can be audited, and how they can be created though the practices specified in the Star Model. The concept of an organization as a bundle of capabilities has shaped both academic thinking and professional practice. Jay's gentle probing helped me, and others, to much better articulate how to think about and improve organizations.

Jay was a mentor in other ways. He was generous with his time and ideas. He would read and comment on papers. He would attend workshops. He would share his ideas and be open to comments on them. He would support alternative points of view. He was clearly the thought leader in organization design but was modest in his personal demeanor and collaborative in his interactions with colleagues. And, he kept learning and continually had fresh ideas. His most recent works were as innovative as his early works. He anticipated the challenges global 
organizations would face and how to respond to them.

He will be missed professionally and personally, but his ideas will far outlive him, and his legacy will be the people and organizations he has shaped.

Dave Ulrich

Professor, University of Michigan

While Jay Galbraith introduced many pioneering ideas and insights on organization design, I am particularly impressed with his sophisticated theorizing about strategic choice and equifinality in designing organizations. Commonplace during the 1970s and 1980s was a deterministic contingency theory, which argued that the internal design of an organization must match its environment (Lawrence \& Lorsch, 1967) and that there is one particular design that is most effective for each contingency (Donaldson, 2001). Galbraith (1977) invoked equifinality arguments to criticize this deterministic formulation of contingency theory. Equifinality introduces an element of choice into the design of organizations because it means that a given outcome can be reached in several equally effective ways and from different initial conditions (Doty, Glick \& Huber, 1993). Galbraith's information-processing model of organization design became highly influential and widely adopted. However, I believe his thinking about equifinality and strategic choice deserves more attention than was generated by our review three decades ago (Van de Ven \& Drazin, 1985). I want to resurrect this review of Galbraith's theorizing because it potentially provides an important way to advance organization design theory and research.

Realistic choices in the design of an organization are always limited by the feasible alternatives available to decision makers. The greater the number of equally effective options for a given situation, the greater the opportunities for managerial choice in contingency theory. Equifinality, or the existence of several feasible and equally effective design options for given contexts, provides choices in designing organizations.

Galbraith argued that a single ideal design for a given setting is not theoretically viable. With his information-processing model, he proposed that in the face of increasing environmental uncertainty managers have at their disposal numerous design solutions. Increased uncertainty may be responded to by centralizing decisions and investing in a higher capacity decision support system, or by decentralizing and creating lateral relations at lower levels of the organization. Both strategies can effectively serve as substitutes or complements of each other and increase information-processing capacity.

Other researchers at the time also recognized some of these alternative strategies. For example, Child's (1977) airline study offered some data in support of Galbraith's assertions by finding that both centralized and decentralized organizations were capable of high performance while operating in similar uncertain environments. Similarly, Khandwalla (1973), Kerr and Jermier (1978), Mintzberg (1979), and Miller (1984) documented a variety of other substitution effects. However, none of these researchers systematically examined how one might theoretically explain equifinality in a contingency theory of organizations.

Galbraith's information-processing model provides a sophisticated theory of equifinality by distinguishing the levels of abstraction of concepts into manipulable manifest variables at the observable level and unobservable latent constructs at a theoretical level, as shown in Figure 1. The basic proposition in Galbraith's $(1973,1977)$ model is that the information-processing requirements an organization faces must match (fit) its capacity to yield information if the organization is to be effective. This may sound like the typical imperative formulation of contingency theory, but in reality it is not. As Figure 1 illustrates, information required and yielded are abstract or latent (theoretical) concepts that result from the contribution of many manifest (measurable and observable) features of organizational context and design. 


\begin{tabular}{|c|c|c|c|}
\hline Ladder of Abstraction & Organization Context & Fit & Organization Design \\
\hline $\begin{array}{c}\text { Latent, Abstract } \\
\text { Concepts }\end{array}$ & Information Required & Efficient Match & Information Yield \\
\hline $\begin{array}{c}\text { Middle-Range } \\
\text { Constructs }\end{array}$ & $\begin{array}{c}\text { Interdependence } \\
\text { Number of exceptions } \\
\text { Number of issues }\end{array}$ & $\begin{array}{c}\text { Mechanisms to reduce } \\
\text { need for information } \\
\text { processing }\end{array}$ & $\begin{array}{c}\text { Mechanisms to increase } \\
\text { capacity to process } \\
\text { information }\end{array}$ \\
\hline $\begin{array}{c}\text { Manifest, Observable } \\
\text { Variables }\end{array}$ & $\begin{array}{c}\text { Environmental } \\
\text { complexity } \\
\text { Task uncertainty } \\
\text { Organization size } \\
\text { Division of labor }\end{array}$ & $\begin{array}{c}\text { Environmental } \\
\text { management } \\
\text { Increase performance } \\
\text { tolerances } \\
\text { Create self-contained } \\
\text { tasks }\end{array}$ & $\begin{array}{c}\text { Invest in IT and MIS } \\
\text { Create lateral relations } \\
\text { Narrow span of control } \\
\text { Planning and goal setting } \\
\text { Rules and procedures } \\
\text { Hierarchy of authority }\end{array}$ \\
\hline
\end{tabular}

Fig 1. Galbraith's Information Processing Model of Organization Design

A variety of contextual and design configurations may produce the same degree of information required and yielded. The choice among alternative combinations is probably a reflection of the decision makers' history, ideology, and performance criteria. For example, in designing an organization using Galbraith's model, a designer will presumably first consider the information-processing requirements confronting the organization. Relevant features would include: environmental complexity, task uncertainty, the size of the organization, and its present division of labor. These factors contribute to the number of issues, exceptions, and interdependencies that require information processing in order to be managed. The organization designer considers these factors jointly not individually. They are aggregated into an abstract theoretical concept called information requirements.

On the organization design side we see a similar pattern. Designers have many alternative mechanisms at their disposal to both increase information-processing capacity in the organization and to reduce the need for it. Hierarchy of authority, rules, planning, spans of control, lateral relations, and MIS are all methods for increasing information capacity. If these mechanisms, relative to their benefits, are viewed as too costly, the designer has a repertoire of alternatives for reducing the need to process information. For example, creating self-contained tasks, slack resources, increasing performance tolerances, extending deadlines, and reducing environmental demands are all methods for decreasing interdependence and the need for coordination and control.

By ascending and descending the ladder of abstraction, Galbraith illustrates an insightful and logical way to advance equifinality and strategic choice in designing organizations. Adopting Galbraith's conceptual moves, the overall organization design problem becomes one of finding ways to combine, substitute, and aggregate alternative options for expanding and contracting an organization's information-processing capacity to achieve a match with the overall amount of information required. Moreover, it becomes one of designing a research study that permits one to empirically examine substitution effects among some of the manifest structural features contributing to the unmeasured latent organizational concept being studied. In Galbraith's case, that concept is information processing; in other cases, it could be another organizing concept such as networking, sense-making, coordination, learning, and so on.

Andrew H. Van de Ven

Professor, University of Minnesota 